\title{
IRES Complexity before IFN-alpha treatment and Evolution of the Viral Load at the Early Stage of Treatment in Peripheral Blood Mononuclear Cells from Chronic Hepatitis C Patients.
}

MA Thélu ${ }^{(1-2)}$, V Leroy ${ }^{(1-2)}$, M Ramzan $^{(2)}$, T Dufeu-Duchesne ${ }^{(1-2)}$, PN Marche ${ }^{(1-2)}$, JP Zarski ${ }^{(1-2)}$.

(1) Département d'Hépato-Gastroentérologie, Hôpital Albert Michallon; Université Joseph Fourier, Grenoble, France

(2) Institut National de la Santé et de la Recherche Médicale U548 ; Université Joseph Fourier Grenoble, France

\begin{abstract}
At the early stage of treatment, IFN alpha-2a induces inhibition of HCV replication. The viral load mainly reflects the degradation rate of the viruses. However, differences in the behaviour of the viral population depend on changes which occurred in the HCV-IRES genome. In this study, cloning and sequencing strategies have allowed to generate a large number of IRES sequences from the PBMCs of eighteen patients (5 women, 13 men) with chronic hepatitis $\mathrm{C}$. The HCV IRES appeared to be highly conserved structurally. However, some variability was found between the different isolates obtained: 467 substitutions with a median of 7 variants/patients. No relationship was observed between pre-treatment IRES complexity and the viral load at the beginning. However, as we considered the evolution of viral load in the PBMCs during the first 3 days of IFN alpha-2a treatment, patients could be classified into 2 groups: Group1, in which viral population continued to replicate and the Group 2, in which the viral load decreased significantly $(\mathrm{p}=0.01727)$. Positioning of the mutations on the predicted IRES secondary structure showed that the distribution of the mutations and their apparition frequency were different between the two groups. At the early stage of treatment, IFN alpha$2 \mathrm{a}$ was efficient to reduce the viral replication in a significant number of cases; mechanisms of response might affect the virus directly. However, pre-treatment genomic variations observed in the 5'NCR of $\mathrm{HCV}$ were not a parameter of later response to antiviral therapy in chronic hepatitis C patients. (244)
\end{abstract}

KEYS WORDS: HCV- IRES, PBMCs, Quasi-species, variants, viral load. 


\section{INTRODUCTION}

Hepatitis C Virus (HCV) is one of the major causative agent of chronic hepatitis, which can result in cirrhosis and ultimately in hepatocellular carcinoma. The cell's first-line of defence is the IFN-induced antiviral response (Pawlotsky., 2003b). However, the antiviral mechanisms by which IFN- $\alpha$ induces modifications of specific immune responses and the establishment of non specific immune antiviral state in the infected cells is unknown. It has been suggested that it may act at various stages of the viral cycle and was likely mediated by several biochemical pathways involving various proteins: 2'-5'-oligoadenylate synthethase (25 OAS), the Mx proteins and the double-stranded RNA-activated protein kinase RNAdependent (dsRNa-PKR) (Giannelli et al., 1993; He \& Katze., 2002; Pawlotsky et al., 1995; Pawlotsky et al., 1996; Samuel., 1998; Samuel., 2001; Shimazaki et al., 2002; Tan \& Katze., 2001; Taylor et al., 2005).

The basis of the treatment of chronic hepatitis $\mathrm{C}$ is interferon- $\alpha$ (IFN- $\alpha$ ) which is currently used in combination with ribavirine, a molecule that potentiates its antiviral effects. Nevertheless, therapeutic failure is frequent and the outcome of antiviral treatment seems to depend on many factors. Indeed, many viruses possess strategies to evade the IFN responses and some virological factors are well known to play a key role in the failure of IFN treatment. Amongst them, it is known that the high rate of virus mutations leads to the generation of a mixture of closely related genomes, the quasispecies, which persist and evolved in the infected patients (Pawlotsky., 2003a; Pawlotsky., 2003c; Rumin et al., 1999; Soler et al., 2002; von Wagner et al., 2003; Vuillermoz et al., 2004).

Similar to coding regions, the $5^{\prime}$ Non Coding Region (5'NCR) is distributed as a quasispecies. Previous studies have shown that this part of HCV genome might accumulate nucleotide substitutions, (Vizmanos et al., 1998) but it appears to be subjected strong conservatory constraints than the other regions of the HCV genome. This is probably due to the need for structural conservation of the mediated translational element: the Internal Ribosome Entry Site (IRES) located in the 5'NC region. This segment (nt 40-372), highly conserved between 
isolates (Soler et al., 2002), has the potential to form a stable secondary and tertiary structure. Changes in the secondary or tertiary structure of IRES as well as changes in primary nucleotide sequence result in a decrease of efficiency of protein translation (Collier et al., 2002; Honda et al., 1999b; Kieft et al., 2001; Laporte et al., 2003; Lerat et al., 2000; Luo et al., 2003).

$\mathrm{HCV}$ is assumed to replicate in PBMCs on the basis of detection of HCV-RNA negative-strand by RT-PCR and in in situ hybridization (Moldvay et al., 1994). Interference with the cells of the immune system is a known mechanism by which viruses evade the host response and become chronically infective (Oldstone., 1997). Infection of extrahepatic tissues is supported by the finding that HCV quasispecies composition differs according to the sample type, i.e., liver, serum, or PBMCs (Cabot et al., 1997; Di Liberto et al., 2006; Fujii et al., 1996; Maggi et al., 1997; Navas et al., 1998). However, the notion of the infection in extrahepatic tissues by HCV is still controversial. Indeed, detection of HCV RNA in the PBMCs might be due to the simple adsorption of viral particles.

The aim of this study is to generate a large number of IRES sequences from PBMCs of the patients with chronic hepatitis $\mathrm{C}$, in order to assess whether quasispecies distribution can be evidenced within the IRES sequences found by using cloning and sequencing strategies. Then, the IRES complexity and its relationship with viral load before IFN alpha-2a treatment will be investigated in order to know if that relationship is a prognostic factor for the response to the treatment. Finally, the relationship between IRES variability before IFN alpha-2a treatment and the evolution of viral load at the early stage of the therapy will be investigated. 


\section{PATIENTS, MATERIAL AND METHODS}

Patients. Eighteen chronic HCV-infected patients were enrolled in CHU de Grenoble (France). All were included in a randomised clinical trial for testing the safety and the efficacy of high daily doses of interferon alpha-2a (Laroféron, Roche) in combination with Ribavirine. At the time of inclusion, each patient had HCV antibodies (ELISA 3), HCV RNA (PCR Monitor, Roche) positive in serum, ALT serum levels more than the upper limit of normal, and the liver biopsy compatible with the diagnosis of chronic viral hepatitis C. Genotyping was carried out after standardized RT-PCR using biotinylated primers (Amplicor, Roche). Among the eighteen HCV genotypes studied, a majority of patients were found to be infected with HCV genotype 1 [1a $(\mathrm{n}=6)-1 \mathrm{a} / \mathrm{b}(\mathrm{n}=1)$ and $1 \mathrm{~b}(\mathrm{n}=7)], 1$ patient with $\mathrm{HCV}$ genotype $2 \mathrm{a} / 2 \mathrm{c}, 1$ patient with genotype $3 \mathrm{a}$ and 2 patients with genotype $4 \mathrm{c} / \mathrm{d}$. The main characteristics of patients are summarized in Table I.

TABLE I. Clinical and Virological Characteristics of the Patients at Entry

\begin{tabular}{|c|c|c|}
\hline $\begin{array}{c}\text { Patients } \\
\mathrm{N}=18\end{array}$ & & \\
\hline Age (years)* & & $44.1 \pm 7.9$ \\
\hline Sex (no of men) & & 13 \\
\hline \multirow[t]{3}{*}{ Mode of transmission } & Blood Transfusion & 4 \\
\hline & Intravenous drug use & 7 \\
\hline & Others / unknown & $3 / 5$ \\
\hline Histological Metavir index** & Activity/Fibrosis & $2.0 \pm 0.8 / 2.0 \pm 0.9$ \\
\hline Genotype & $1 a-1 a / 1 b-1 b-2 c-3 a-4 c / d$ & $5-1-8-1-1-2$ \\
\hline ALAT level* & & $2.3 \pm 1.8$ \\
\hline Serum Viral load (UI/mL) (log)* & & $6.2 \pm 6.2$ \\
\hline PBMCs viral load $(\mathrm{UI} / \mathrm{mL})(\log )^{*}$ & & $3.2 \pm 3.2$ \\
\hline
\end{tabular}

* mean \pm one standard deviation

** median

Treatment. Patients were randomised to receive an induction course of IFN alpha-2a (Laroferon, Roche) subcutaneously 18MUI/d for 2 days followed by 9MUI/d for 12 days. In addition, all patients received $3 \mathrm{MUI} / \mathrm{d}$ of IFN alpha-2a for 20 weeks followed by 3 MUI 
twice a week for 24 weeks. Ribavirin (1000-1200 mg) was given in association with IFN alpha2a for 48 weeks to all patients.

Serum viral load was determined at the start of the treatment i.e.:D0, then D2, D3, D4, W2, W4 and W12.

Response to therapy. Eighteen patients with chronic hepatitis C were strictly selected and paired according to age, sex, mode of infection and duration of disease. Then they were separated into two groups according to their response to antiviral therapy. Patients with undetectable serum HCV RNA after six-month follow-up were classified as sustained responders $(\mathrm{SR}=9 / 18)$. Patients with continuously positive HCV RNA in the serum were considered as non-responders $(\mathrm{NR}=9 / 18)$.

Preparation of serums and PBMCs. Peripheral venous blood was collected in EDTA-treated tubes. Serum samples were obtained by centrifugation $\left(10 \mathrm{~min}-1400 \mathrm{rpm}-4^{\circ} \mathrm{C}\right)$ of the blood samples at the start of the treatment i.e.:D0. The HCV concentration was then measured in these samples by using the Amplicor Monitor Test Kit (Hoffmann-La Roche AG).

The PBMCs were isolated by Ficoll density gradient centrifugation at the start of the treatment and $72 \mathrm{~h}$ after the start of the treatment (D4) and were stored in liquid nitrogen in RPMI medium containing 10\%DMSO ( 3 aliquots of $>10^{7}$ cells for each patient).

In vivo cells culture. The frozen PBMCs pellets $\left(>10^{7}\right.$ cells) were incubated at $37^{\circ} \mathrm{C}$ for 10 min with $1 \mathrm{~mL}$ RPMI supplemented with $20 \%$ Human $\mathrm{AB}$ serum and the mixture was centrifuged for $10 \mathrm{~min}$ at $1400 \mathrm{rpm}$. PBMCs adjusted to $1 \times 10^{6}$ cells/well in PBS were plated in duplicate in 24 -well plate and cultured at $37^{\circ} \mathrm{C}$ in a humidified atmosphere with $50 \mathrm{~mL} / \mathrm{L}$ $\mathrm{CO}_{2}$ for $30 \mathrm{~min}$. Then samples were pooled in order to obtain $2 \times 10^{6}$ cells.

In order to eliminate the extra cellular HCV possibly adsorbed on the mononuclear cells surface, an adapted assay was performed (Cribier et al., 1995). Each sample was treated with trypsin (final concentration $0.05 \%$ ) and EDTA (final concentration $0.02 \%$ ) before incubation. 
Trypsin activity was then blocked by the addition of foetal calf serum (Invitrogen) (final concentration 10\%) and the pellets were washed in PBS. Before manual extraction, the pellet was resuspended in $100 \mu \mathrm{L}$ of PBS followed by quantification with COBAS Amplicor.

In vitro cells culture. The frozen PBMCs pellets $\left(>10^{7}\right.$ cells) were defrosted in the same way as mentioned above (10 min with 1mL RPMI supplemented with 20\% Human AB serum centrifuged for $10 \mathrm{~min}$ at $1400 \mathrm{rpm}$ - . adjusted to $1 \times 10^{6}$ cells/well in PBS - plated in duplicate in 24 -well plate). Then, they were cultured for 6 hours, at $37^{\circ} \mathrm{C}$ in a humidified atmosphere with $50 \mathrm{~mL} / \mathrm{L} \mathrm{CO}_{2}$ in the absence or presence of IFN at a concentration of 100 $\mathrm{UI} / 10^{6}$ cells or presence of $\mathrm{IFN}\left(100 \mathrm{UI} / 10^{6}\right.$ cells $)$ plus Ribavirine at a concentration of $600 \mathrm{ng} / 10^{6}$ cells. Then the samples were pooled in order to obtain $2 \times 10^{6}$ cells and underwent for the trypsin treatment before quantification of the viral load.

Quantification of $\mathrm{HCV}$ in the PBMCs : In order to adapt the standardised method for quantification of HCV in the PBMCs (i.e.: The COBAS AMPLICOR HCV MONITOR v 2.0 standard serum protocol provides manual HCV RNA extraction, uses an automated RT-PCR to co-amplify an internal RNA quantification calibrator and the viral quantification was achieved by comparison to the internal RNA quantification calibrator), the following assays were performed: i) determination of the optimal cell number for the assay by testing $1 \times 10^{6}, 2$ x $10^{6}, 5 \times 10^{6}$ isolated PBMCs, $2 \times 10^{6}$ cells were retained; ii) the pellet was resuspended from $1 \mathrm{ml}$ to $100 \mu \mathrm{l}$, which represented a ten-fold increment in the target RNA to be amplified and would consequently increase the assay sensibility. Taking these modifications under consideration, the formula calculated was:

Adsorbance HCV x dilution factor $\times 200 \times 2 \times$ number of cells Adsorbance IQS $x$ dilution factor

The linearity of the assay range was between 50 and $5.10^{5}$ RNA copies $/ 2.10^{6}$ cells. The results regarding the viral load were expressed as $\log$ of multiples of $\mathrm{UI} / \mathrm{mL}(=2.7 \mathrm{Copies} / \mathrm{mL})$. 
Detection of 5'NC variants in PBMCs by cloning and sequencing. HCV specific RNA was extracted from PBMCs $(100 \mu \mathrm{L})$ using QIAamp viral RNA Kit (Qiagen, Courtaboeuf, France) according to the manufacturer's protocol. The 5'NCR was amplified by RT/ PCR by using the set of primers designed from the IRES region (IRES forward (nt 21-40): gac act cca cca tga atc ac, IRES reverse (nt 360-374): gtt tt ctt tga ggt tta gg). PCR was carried out for 40 cycles $\left(94^{\circ} \mathrm{C}-30 \mathrm{sec}, 55^{\circ} \mathrm{C}-15 \mathrm{sec}, 72^{\circ} \mathrm{C}-30 \mathrm{sec}\right)$. The final PCR products of $354 \mathrm{bp}$ were analysed by electrophoresis on a $2 \%$ agarose gel, stained with ethidium bromide, and observed under UV light. These PCR products were purified with QIAquick PCR purification kit (Qiagen) as specified by the manufacturer and quantified by UV Spectrophotometry. Amplicons were directly ligated into pCR2.1-TOPO vector (InVitrogen, San Diego, CA), $1 \mathrm{~min}$ at room temperature. Recombinant plasmids were used to transform Escherichia coli competent cells (InVitrogen, San Diego, CA). Transformants were grown on Luria-Bertani Broth agar plates containing ampicillin $(100 \mathrm{mg} / \mathrm{ml})$ and incubated overnight at $37^{\circ} \mathrm{C}$. More than twenty four independently isolated cDNA clones from PCR products were selected. Plasmid DNAs containing 5'NCR sequences were extracted by the alkaline lysis method with the Concert Rapid Plasmid Purification System (Life technologies, GIBCO BRL products). A total of $352 / 456$ clones were quantified by spectrophotometry and sequenced bidirectionnally by the ABI PRISM automated sequencer by using M13 universal primers. Electrophoresis data obtained by the automatic sequencer were analysed by using the sequences navigator BLAST search. Artefactual quasispecies could result from polymerase-derived errors introduced during amplification or from selection during amplification and cloning procedures. A thermostable polymerase with proof-reading functions (BRL Life Technologies, Gaithersburg, MD) was used in order to minimise these artefacts. Moreover, if incorporation errors from polymerase were implicated, an increment in mutations from single mutant to multiple mutants should have been observed, which was not the case. These two points 
argued in favour of the reliability of our sequence data. Sequences were aligned and compared with the sequence prototypes or the nearest prototype (PBIL, IBCP, Lyon). Sequence alignments were reviewed manually; mutation sites were identified by the CLUSTAL alignment multiple software and edited prior to phylogenetic analysis. Sequence gaps were excluded from the analysis. The non random distribution of the observed substitutions was incompatible with artefacts related to errors made by DNA polymerase during PCR reaction. In some patients, the HCV-IRESs appeared chimeric, with successive blocks of sequence reminiscent of different genotypes. This may suggest the multiple recombination events.

Phylogenetic tree. Viral sequences were aligned by using CLUSTAL X software version 1.8. Neighbor joining analyses were performed by using DNADIST and NEIGHBOR in the PHYLIP package, version3.572, with pairwise distances estimated by using Kimamura two parameters distances. We analysed the robustness of different branches by bootstrapping (103 replicates). Tree was visalized with Tree View v32.

Statistical analysis. Results were presented as means \pm standard error of the mean or as percentages. Differences between the 2 groups were assessed by Spearman's correlation and coefficient test, Kruskall-Wallis test and Wilcoxon test. Factors with $\mathrm{P}<0.05$ were considered as significant. 


\section{RESULTS}

\section{I - Quasispecies distribution of the HCV-5'NCR in the PBMCs of patients.}

The PBMCs from 18 patients (5 women, 13 men) with chronic HCV diseases were collected before treatment initiation. Quantification of $\mathrm{HCV}$ in the PBMCs was assayed according to adaptive modification of the standard method. A fragment of 341 nt-long 5'Non-coding region (5'NCR) including the IRES was analysed. After cloning in Escherichia coli, an average of 19 clones from each patient was sequenced and each IRES sequence was aligned with the reference sequence strands: HCV-J4 for genotype 1b (Okamoto et al., 1992), HCV NZL1 for genotype 3a (Okamoto et al., 1993) and HCV-S83 or HCV CH-563 for genotype 2 or with the closest prototype reference strains after BLAST research. Although the 5 'NC region appeared to be highly conserved structurally; a quasispecies distribution was found between the different isolates obtained. Indeed, 467 substitutions distributed all along the IRES were included in 131 variants (>7 variants/patients). These variants were characterised by the presence of both major variants; without any nucleotidic changes, accounting for $1 / 3$ of the clones studied and, the minor variants; accounting for $2 / 3$ of the clones which undergo changes.

\section{II - Location of the mutations on the predicted secondary and tertiary structures of $\mathrm{HCV}$ -} IRES.

The observed 467 mutations were then positioned on the predicted IRES secondary structure (Honda et al., 1999b) (Figure 1) and out of the 341 nucleotides forming the IRES sequence, only 102 nucleotidic sites underwent mutations. It means that the nucleotidic change observed on a particular site will be found on the numerous other clones of the same patient. These particular sites, gathering numerous substitutions ( $>2 \%$ of mutations), were called “clustering position”. Alignment of sequences confirmed that these clustering sites did not result by cross contaminations. Indeed, in each patient, numerous sequences presented both clustering positions and minor mutations and these minor mutations were different among 
isolates of the same patient. Nine clustering positions gathering $3 / 4(70 \%-332 / 467)$ of the total mutations were observed. These 9 clustering positions were evident for nucleotidic sites 78, 104, 107 in domain II, gathered 35.4\% of the changes (166/467); sites 183, 204, 206 in domain IIIb gathered $15.4 \%$ of the mutations (72/467); position 243 in domain IIIc and 259 in domain IIId gathered $4.5 \%(21 / 467)$ and $2.5 \%$ of the mutations (12/467) respectively. In the smaller stem-loop IV; $13.1 \%$ (61/467) of mutations on position 340 were found. Out of the 467 mutations, only one mutation ( $\mathrm{U}$ to $\mathrm{C}$ ) on nt 343 inside the AUG-4 initiator codon was observed. As the paired regions without compensation were very important for the stability of the structure, a majority of mutations occurred in the paired regions were such that maintained the base-pairing. Out of the 467 changes observed in the viral population, only a minority (21.5\%) would be expected to result in a loss of base-pairing, i.e. an alteration of the IRES structure. Changes on some positions were transferred in a concomitant way at numerous clones (29\%). They acted on positions 78-104-206 and 259 and on positions 107, 183 and 340. Finally, the GGG triplet between nucleotides 266 and 268 of the hexanucleotide apical loop of stem loop III was conserved in all of the observed sequences except the clones found in two patients for which 2 mutations of nt 267 ( $\mathrm{G}$ to $\mathrm{C}$ ) and two deletions of nt $\mathrm{G}$ in position 268 have been found.

\section{III-Relationship between pre-treatment IRES complexity and the viral load}

As the global viral population infecting PBMCs was considered at the outset, the viral load was on average of $1591 \pm 1637 \mathrm{UI} / \mathrm{mL}\left(3.2 \log _{10} \pm 3.2 \mathrm{UI} / \mathrm{mL}\right)$, whereas, the number of viral genomes in the serum was on average of $1660712 \pm 1617850 \mathrm{UI} / \mathrm{mL}\left(6.2 \log _{10} \pm 6.2 \mathrm{UI} / \mathrm{mL}\right)$. No relationship was observed between pre-treatment IRES variability and the viral load at Day 0 (data not shown).

\section{$I V-E v o l u t i o n$ of viral load at the early stage of treatment}


During the first three days of treatment with IFN alpha-2a, the viral load in PBMCs decreased by $50.3 \%\left(2.9 \log _{10} \pm 3.1\right.$ vs $\left.3.2 \log _{10} \pm 3.2 \mathrm{UI} / \mathrm{mL}-\mathrm{p}=0.1341\right)$ and by $88 \%\left(5.3 \log _{10} \pm 5.3\right.$ vs $6.2 \log _{10}$ $\pm 6.2 \mathrm{UI} / \mathrm{mL}-\mathrm{p}=0.0001322)$ in the serum. A decrease occurred significantly in the serum, whereas, a decreasing tendency was noted in the PBMCs.

In parallel, the study of the evolution of viral load in ex vivo 6 hours cultured cells showed that these values decreased by $94.5 \%\left(1.9 \log _{10} \pm 2.2\right.$ vs $3.2 \log _{10} \pm 3.2 \mathrm{UI} / \mathrm{mL}-$ $\mathrm{p}=0.00003642)$ when the cells were treated with IFN alpha-2a alone and by $94.2 \%\left(2.0 \log _{10}\right.$ \pm 2.3 vs $\left.3.2 \log _{10} \pm 3.2 \mathrm{UI} / \mathrm{mL}-\mathrm{p}=0.00001015\right)$ when the cells were treated with IFN alpha-2a plus ribavirine.

Decrease of viral load in PBMCs was more important in ex vivo experiment than in in vivo treatment. Addition of ribavirine did not affect the ex vivo response. No relationship was observed between pre-treatment IRES variability and the viral load at the early stage of the treatment.

The evolution of viral load during the first three days of treatment was considered and the patients might be classified into two groups:

- Group 1: included $1 / 3$ of the patients $(\mathrm{N}=6)$, whose viral load in the PBMCs did not decrease during the therapy (increasing by $104 \%)\left(3.2 \log _{10} \pm 3.3\right.$ vs $2.9 \log _{10} \pm 3.0 \mathrm{UI} / \mathrm{mL}$ $-\mathrm{p}=0.4848)$. In the serum, a significant decrease of viral load by $82 \%$ was noted $(5.4$ $\log _{10} \pm 6.1$ vs $6.2 \log _{10} \pm 6.3 \mathrm{UI} / \mathrm{mL}-\mathrm{p}=0.09307$ ). As the later response to the treatment (more than 6 months) was considered, it should be notice that 4 out of 6 patients included in this group were non responders.

In parallel, a significant decrease by $83 \%$ of the viral load occurred in ex vivo study $\left(2.1 \log _{10} \pm 2.3\right.$ vs $\left.2.9 \log _{10} \pm 3.0 \mathrm{UI} / \mathrm{mL}-\mathrm{p}=0.1797\right)$ when the cells were cultured with IFN alpha-2a for 6 hours. Obviously, in ex vivo experiment, viral resistance to treatment has disappeared. 
- Group 2: This group included the remaining $2 / 3$ of the patients $(\mathrm{N}=12)$ with a significant decrease of the viral load by $77 \%$ in the PBMCs $\left(2.7 \log _{10} \pm 2.7\right.$ vs $3.3 \log _{10} \pm$ $3.2 \mathrm{UI} / \mathrm{mL}-\mathrm{p}=0.01727)$ and by $90 \%\left(5.2 \log _{10} \pm 5.3\right.$ vs $\left.6.2 \log _{10} \pm 6.1 \mathrm{UI} / \mathrm{mL}-\mathrm{p}=0.000656\right)$ in the serum during the first three days of the therapy. However, the later response to treatment (more than 6 months) has shown that 3 out of 12 patients of this group were non responders.

In addition, during the first 6 hours of cultured cells with IFN alpha-2a, viral load decreased by $97 \%\left(1.8 \log _{10} \pm 2.1\right.$ vs $\left.3.3 \log _{10} \pm 3.2 \mathrm{UI} / \mathrm{mL}-\mathrm{p}=0.0001955\right)$. It was noticed that even in this group, the viral resistance mechanisms might have disappeared in the cultured cells but the differences between the evolution of viral load values in in vivo and ex vivo experiments were less notable (77\% vs 97\%).

Briefly, i) in vivo: viral load decreased in the serum of both groups (decreasing $82 \%$ and $90 \%$ respectively), but the evolution of viral load in the PBMCs of both groups was different: increasing by $104 \%$ in group 1 and decreasing by $77 \%$ in group 2 ; ii) ex vivo: as significant decreases of viral load in PBMCs occurred in both groups, however, addition of IFN alpha-2a in the cultured PBMCs of group1 was less effective than in the group 2 ( $83 \%$ vs $97 \%)$.

\section{V-Analysis of relationship between viral load and IRES complexity in both groups:}

Comparison between the average PBMCs viral load from group 1 and 2 at the beginning of therapy showed no significant difference $\left(2.9 \log _{10} \pm 3.0\right.$ vs $\left.3.3 \log _{10} \pm 3.2 \mathrm{UI} / \mathrm{mL}-\mathrm{p}=0.09182\right)$. However, in group 1: the corresponding viral population gathered $37 \%$ of the total quasispecies (49/131). The 303 mutations (303/467 - 65\%) observed in these variants were mainly (254/303-84\%) distributed on 7 clustering sites 78, 104, 107, 183, 206, 243 and 340 (Figure 2); in group 2: the corresponding viral population included $63 \%$ of the variants $(82 / 131)$ which concentrated 164 mutations (164/467 - 35\%). Out of these, 81/164 (49\%) mutations which 
composed of these quasispecies appeared on 6 clustering sites such as 78, 104, 107, 204, 206 and 259, whereas, changes on site 183, 243, and 340 were undetectable (Figure 3).

It was noted that in group1, less variant was observed than in group 2, but it gathered more changes (303 and 164 respectively - $\mathrm{p}=0.001045$ ). Significant difference between group1 and group 2 for the number of clustering substitutions ( 254 vs 81 clustering mutations $-\mathrm{p}=0.0006438$ ) was observed. In both groups, mutations were distributed all along the IRES genome; however in group 1, majority of them were concentrated on few nucleotidic sites.

Some positions (78, 104, 107 and 206) were retrieved in both groups but mutations on these sites were encountered more frequently in group1 than in group 2 (Fig 2-3): (i) in stem-loop II, U to $\mathrm{C}$ at nt 78 (4.3\% vs $1.5 \%), \mathrm{C}$ to $\mathrm{U}$ at nt 104 (4.3\% vs 1.3\%), G to A at nt 107 (17.6\% vs 6.6\%); (ii) in stem-loop III, nucleotide C insertion at 206 (4.3\% vs 1.3\%). In addition, mutations $\mathrm{C}$ to $\mathrm{U}(6.2 \%)$ at position 183 in domain III, G to A (4.5\%) at nt 243 in stem-loop IIIc and C to U (13.1\%) at position 340 in stem-loop IV, occurred only in group1. In contrast, mutations C to A (3.6\%) at position 204 in bulge IIIb and mutations U to C at nt 259 (2.5\%) in domain IIId were observed only in the patients of group 2 .

Study of stem-loops showed minor other differences between the 2 groups. Indeed, two of the five short ORFs (Open Reading Frame) which may encode very small peptides (Han et al., 1991; Inchauspe et al., 1991) located in domain II, start at positions 85-87 (AUG-1) and 96-98 (AUG2). Mutation on nt 87 ( $\mathrm{G}$ to $\mathrm{C}$ ) inside AUG-1, on positions 96 (A to $\mathrm{G}$ ) and 97 ( $\mathrm{U}$ to $\mathrm{C}$ ) inside AUG-2 were encountered only in viral population from group 1. In the smaller bulge IV, mutations at nt 340 and 350, flanking both sides of the AUG-4 initiator codon were found. Upstream mutations frequency of this initiator codon was present only in group 1 . In addition, one mutation was observed at nt 343 inside the AUG-4 initiator codon in group 2. 


\section{DISCUSSION}

The presence of negative-strand RNA in PBMCs from infected patients has been demonstrated (Ducoulombier et al., 2004; Lanford et al., 1995; Laskus et al., 2000; Lerat et al., 2000; Moldvay et al., 1994) which suggests the existence of a potentially important extrahepatic site of HCV replication (Bain et al., 2001; Laporte et al., 2003; Roque Afonso et al., 1999; Roque-Afonso et al., 2005). Many viruses possess strategies for evading or limiting the interferon-induced antiviral response and lead to progression of a disease. HCV-IRES variability is one of the mechanisms by which the virus might escape the treatment. Indeed, strong selection pressure against any mutations in this region alters the structure of the HCV-IRES (Soler et al., 2002). Moreover, previous works (Gale et al., 1998a; Gale et al., 1998b; Odreman-Macchioli et al., 2001; Odreman-Macchioli et al., 2000) have demonstrated that correct RNA-protein interactions involving the HCV-IRES are highly dependent on both the primary nucleotide sequence and its ability to form complex of secondary and tertiary RNA structures. Recently, Dash et al (2005) have showed that IFNalpha, -beta, and gamma inhibit replication of $\mathrm{HCV}$ in a cell culture model by directly inhibiting the internal translation site of HCV-IRES.

Clustering sites observed in HCV-IRES sequences were mainly located in domains II (sites 78,104,107 - 35\%), III (sites 183,204,206,243,259 - 22\%) and IV (site 340 - 13\%) (Fig 1) and mutations on positions 107, 204 and 243 might reflect a viral phenotype that was particularly well adapted for replication in the lymphoid cells with a specifically enhance HCV translation in these cells (Lerat et al., 2000; Maggi et al., 1997; Nakajima et al., 1996; Navas et al., 1998; Shimizu et al., 1997). In spite of that, no significant difference in viral load (reflecting enhance of translational activity) was related to these nucleotidic sites in this study. These results agreed with what it was mentioned previously (Yamamoto et al., 1997): sequence variability of HCV-IRES was not appearing to correlate with any difference in HCV-RNA concentration in the PBMCs which 
reflects the level of $\mathrm{HCV}$ replication. Obviously, viral population has established an equilibrium between the quasispecies and immune constraints.

In parallel of this quasispecies characterization, viral load of the individuals who carried these variants was studied. Before treatment, viral load in the serum was 3 log upper than in the PBMCs $(6.2 \log$ vs $3.2 \mathrm{log})$. During the first three days of in vivo treatment, viral load decreased more significantly in the serum than in the PBMCs (88\% vs 50\%). These results agreed with authors who indicated that human lymphoid cells were permissive for replication of HCV but at low-level (Shimizu et al., 1997; Shimizu et al., 1993), nevertheless, HCV-RNA level in the serum remained high $(5.3 \log$ vs $6.2 \mathrm{log})$. Obviously, IFN treatment has an impact on the circulating viral particles, but the intra cellular viruses seemed to be affected in a less significant manner. Then the evolution of in vivo viral load during the first three days of therapy was observed, and the results allowed the patients to be classified into two groups. These two groups behaved differently according to the in vivo or ex vivo context. Indeed, during in vivo treatment, viral load was affected by both mechanisms: one by which the viral population escape from the treatment and continued to replicate and another by which IFN alpha-2a has an impact on the viral genome. In ex vivo treatment, out of the context, $\mathrm{HCV}$ might not replicate and might not evade the treatment or the immune pressure, as the viral load decreased significantly. These results suggested that at the early stage of the treatment, mechanisms of response affected directly on the capacity of the virus to replicate, whereas, the adaptive immunological response did not occur yet. As viral replication depends on the IRES integrity, it might be suggest that IRES complexity play a key role in this phenomenon.

Previous results (Laporte et al., 2000) have demonstrated that IRES activity was independent of the number of additional mutations detected but that the nucleotide location which played the most important role for IRES efficiency. So location and frequency of the 
clustering mutations observed before therapy were investigated in order to understand the behaviour of the viral population.

The HCV-IRES domain II induces conformational changes on the ribosome which have been implicated in the decoding process (Kalliampakou et al., 2002). The introduction of mutations in this domain can cause a moderate or total loss of translational ability (Kalliampakou et al., 2002; Kim et al., 2003). In this study, three clustering sites (78-104-107) located in base paired region on the stem-loop II gathered numerous changes (35.4\%). These mutations were higher in patients among whom virus continued to replicate than in patients with decrease of viral population. Viral load which reflect the ability of HCV to replicate was not affected by these mutations. However, the importance of stem-loop II for IRES function has been discussed controversially and the changes that occurred in the base-paired regions have not been demonstrated as affecting the translational activity of HCV-IRES (Da Rocha Gomes et al., 2004; Honda et al., 1999a; Kalliampakou et al., 2002; Odreman-Macchioli et al., 2001; Reynolds et al., 1996; Rijnbrand et al., 1995).

The apical stem-loop IIIb has been shown to bind initiation factor eIF3. Disruption of the secondary structure of this region results in the loss of both eIF3 binding and IRES activity (Collier et al., 2002; Odreman-Macchioli et al., 2001). In this study, changes on position 183, located in the stem loop IIIb, were often associated with the changes on positions 107 and 340 in group 1. These latest mutations observed only in the group of patients whose viral load did not change could lead to stabilisation of the IRES structure. In the same way, insertion on site 206 was associated with mutations on position 204 in group 1 and, might likely contribute to stabilise the IRES complexity.

The correct secondary structure of IIId has also been suggested to be important for the binding of ribosomal protein S9. Indeed, mutations within the IIId stem-loop abolish IRES activity (Kieft et al., 2002). In this study, the mutated site, gathering the most frequent changes located on the stem-loop IIId, was on position 259 found only in the patients with decreasing 
viral population. Consequently, it is suggested that the mutation encountered in this region did not allow the three-dimensional structure to be conserved between isolates of varying primary sequence and could impair viral replication. Finally, the changes observed on position 243 (likely important for maintain the IRES structure) encountered only in the patients with stabilisation or increase of viral load, might serve the virus to escape from the treatment, whereas, mutations on site 259 could expose the virus to IFN action.

The mutations observed at positions 340 and 350, flanking both sides of the AUG-4 initiator codon, inside the smaller stem-loop IV which modulated the translation during virus replication (Collier et al., 2002), were only found in the patients with increasing viral population. This result was agreed with Honda et al., (1996) who have demonstrated that mutations which destabilise the stem-loop IV restored translation to normal.

Study of the later response to treatment showed that even in group 2 with a significant decrease of the viral load at the start, some patients did not respond to the therapy at the later stage. IFN alpha-2a induced inhibition definitively affected the virus only in ex vivo replication. In contrast, in the group in which the virus continued to replicate during the first three days of treatment, some individuals respond in the later stage of therapy. These results might suggest that, at the early stage of therapy, the virus alone was the key of the response, and that the HCV complexity influenced the response to treatment. In contrast, all along the treatment, other mechanisms implying host immune defences were set up. These observations agreed with authors (von Wagner et al., 2003) who concluded that although quasispecies evolution during IFN therapy is common, it occurs after a wide range of time intervals after initiation of therapy. However in some cases, at the early stage of treatment, escape mechanisms were set up quickly, reflecting a fast adaptation of the virus to its environment.

Obviously some viral population are more sensitive to the therapy than others but these mechanisms remaine to be explored. Although, IFN alpha-2a was efficient to reduce the 
viral replication in a significant number of cases at the early stage of therapy, non responsiveness to IFN cannot be explained exclusively by the changes in quasispecies. Consequently, pre-treatment genomic variations observed in the 5'NCR of HCV are not parameters of later response to the antiviral therapy in chronic hepatitis $\mathrm{C}$ patients.

Several genomes and/or viral protein functions and their interactions with numerous host cell functions are likely involved in $\mathrm{HCV}$ resistance to the non specific antiviral action of IFN alpha-2a in the infected cells.

\section{ACKNOWLEDGMENTS}

This work was supported by the grant of UF 1527 from the Délégation Régionale à la Recherche Clinique. The authors thank Sylvie Larrat for its assistance in the construction of Phylogenetic trees and Dr Gaynor Green for reading this manuscript. 


\section{REFERENCES}

Bain C, Fatmi A, Zoulim F, Zarski JP, Trepo C, Inchauspe G. 2001. Impaired allostimulatory function of dendritic cells in chronic hepatitis $\mathrm{C}$ infection. Gastroenterology. 120: 512-24.

Cabot B, Esteban JI, Martell M, Genesca J, Vargas V, Esteban R, Guardia J, Gomez J. 1997. Structure of replicating hepatitis C virus (HCV) quasispecies in the liver may not be reflected by analysis of circulating HCV virions. J Virol 71: 1732-4.

Collier AJ, Gallego J, Klinck R, Cole PT, Harris SJ, Harrison GP, Aboul-Ela F, Varani G, Walker S. 2002. A conserved RNA structure within the HCV IRES eIF3-binding site. Nat Struct Biol 9: 375-80.

Cribier B, Schmitt C, Bingen A, Kirn A, Keller F. 1995. In vitro infection of peripheral blood mononuclear cells by hepatitis C virus. J Gen Virol 76: 2485-91.

Da Rocha Gomes S, Dausse E, Toulme JJ. 2004. Determinants of apical loop-internal loop RNA-RNA interactions involving the HCV IRES. Biochem Biophys Res Commun 322: 820-6.

Dash S, Prabhu R, Hazari S, Bastian F, Garry R, Zou W, Haque S, Joshi V, Regenstein FG, Thung SN. 2005. Interferons alpha, beta, gamma each inhibit hepatitis C virus replication at the level of internal ribosome entry site-mediated translation. Liver Int 25: 580-94.

Di Liberto G, Roque-Afonso AM, Kara R, Ducoulombier D, Fallot G, Samuel D, Feray C. 2006. Clinical and therapeutic implications of hepatitis C virus compartmentalization. Gastroenterology. 131: 76-84.

Ducoulombier D, Roque-Afonso AM, Di Liberto G, Penin F, Kara R, Richard Y, Dussaix E, Feray C. 2004. Frequent compartmentalization of hepatitis C virus variants in circulating B cells and monocytes. Hepatology. 39: 817-25. 
Fujii K, Hino K, Okazaki M, Okuda M, Kondoh S, Okita K. 1996. Differences in hypervariable region 1 quasispecies of hepatitis $\mathrm{C}$ virus between human serum and peripheral blood mononuclear cells. Biochem Biophys Res Commun 225: 771-6.

Gale M, Jr., Blakely CM, Kwieciszewski B, Tan SL, Dossett M, Tang NM, Korth MJ, Polyak SJ, Gretch DR, Katze MG. 1998a. Control of PKR protein kinase by hepatitis $\mathrm{C}$ virus nonstructural 5A protein: molecular mechanisms of kinase regulation. Mol Cell Biol 18: 5208-18. 22: Duverlie G et al. Sequence analysis of the NS5A...[PMID: 9634077]Related Articles, Links.

Gale MJ, Jr., Korth MJ, Katze MG. 1998b. Repression of the PKR protein kinase by the hepatitis C virus NS5A protein: a potential mechanism of interferon resistance. Clin Diagn Virol 10: 157-62.

Giannelli G, Antonelli G, Fera G, Dianzani F, Schiraldi O. 1993. 2',5'-Oligoadenylate synthetase activity as a responsive marker during interferon therapy for chronic hepatitis C. J Interferon Res 13: 57-60.

Han JH, Shyamala V, Richman KH, Brauer MJ, Irvine B, Urdea MS, Tekamp-Olson P, Kuo G, Choo QL, Houghton M. 1991. Characterization of the terminal regions of hepatitis C viral RNA: identification of conserved sequences in the 5' untranslated region and poly(A) tails at the 3' end. Proc Natl Acad Sci U S A. 88: 1711-5.

He Y, Katze MG. 2002. To interfere and to anti-interfere: the interplay between hepatitis C virus and interferon. Viral Immunol 15: 95-119. 13: Pflugheber J et al. Regulation of PKR and IRF-1 d...[PMID: 11904369]Related Articles, Links.

Honda M, Beard MR, Ping LH, Lemon SM. 1999a. A phylogenetically conserved stem-loop structure at the $5^{\prime}$ border of the internal ribosome entry site of hepatitis $\mathrm{C}$ virus is required for cap-independent viral translation. J Virol 73: 1165-74. 
Honda M, Brown EA, Lemon SM. 1996. Stability of a stem-loop involving the initiator AUG controls the efficiency of internal initiation of translation on hepatitis C virus RNA. Rna. 2: 955-68.

Honda M, Rijnbrand R, Abell G, Kim D, Lemon SM. 1999b. Natural variation in translational activities of the 5' nontranslated RNAs of hepatitis C virus genotypes 1a and 1b: evidence for a long-range RNA-RNA interaction outside of the internal ribosomal entry site. J Virol 73: 4941-51.

Inchauspe G, Zebedee S, Lee DH, Sugitani M, Nasoff M, Prince AM. 1991. Genomic structure of the human prototype strain $\mathrm{H}$ of hepatitis $\mathrm{C}$ virus: comparison with American and Japanese isolates. Proc Natl Acad Sci U S A. 88: 10292-6.

Kalliampakou KI, Psaridi-Linardaki L, Mavromara P. 2002. Mutational analysis of the apical region of domain II of the HCV IRES. FEBS Lett 511: 79-84.

Kieft JS, Zhou K, Grech A, Jubin R, Doudna JA. 2002. Crystal structure of an RNA tertiary domain essential to HCV IRES-mediated translation initiation. Nat Struct Biol 9: 3704.

Kieft JS, Zhou K, Jubin R, Doudna JA. 2001. Mechanism of ribosome recruitment by hepatitis C IRES RNA. Rna 7: 194-206.

Kim YK, Lee SH, Kim CS, Seol SK, Jang SK. 2003. Long-range RNA-RNA interaction between the $5^{\prime}$ nontranslated region and the core-coding sequences of hepatitis $\mathrm{C}$ virus modulates the IRES-dependent translation. Rna 9: 599-606.

Lanford RE, Chavez D, Chisari FV, Sureau C. 1995. Lack of detection of negative-strand hepatitis C virus RNA in peripheral blood mononuclear cells and other extrahepatic tissues by the highly strand-specific rTth reverse transcriptase PCR. J Virol. 69: 807983. 
Laporte J, Bain C, Maurel P, Inchauspe G, Agut H, Cahour A. 2003. Differential distribution and internal translation efficiency of hepatitis $C$ virus quasispecies present in dendritic and liver cells. Blood 101: 52-7. Epub 2002 Jun 28. Write to the Help Desk NCBI | NLM | NIH Department of Health \& Human Services Privacy Statement | Freedom of Information Act | Disclaimer.

Laporte J, Malet I, Andrieu T, Thibault V, Toulme JJ, Wychowski C, Pawlotsky JM, Huraux JM, Agut H, Cahour A. 2000. Comparative analysis of translation efficiencies of hepatitis $\mathrm{C}$ virus 5' untranslated regions among intraindividual quasispecies present in chronic infection: opposite behaviors depending on cell type. J Virol 74: 10827-33.

Laskus T, Radkowski M, Wang LF, Nowicki M, Rakela J. 2000. Uneven distribution of hepatitis $\mathrm{C}$ virus quasispecies in tissues from subjects with end-stage liver disease: confounding effect of viral adsorption and mounting evidence for the presence of lowlevel extrahepatic replication. J Virol. 74: 1014-7.

Lerat H, Shimizu YK, Lemon SM. 2000. Cell type-specific enhancement of hepatitis C virus internal ribosome entry site-directed translation due to $5^{\prime}$ nontranslated region substitutions selected during passage of virus in lymphoblastoid cells. J Virol 74: 7024-31.

Luo G, Xin S, Cai Z. 2003. Role of the 5'-proximal stem-loop structure of the 5' untranslated region in replication and translation of hepatitis C virus RNA. J Virol 77: 3312-8.

Maggi F, Fornai C, Vatteroni ML, Giorgi M, Morrica A, Pistello M, Cammarota G, Marchi S, Ciccorossi P, Bionda A, Bendinelli M. 1997. Differences in hepatitis C virus quasispecies composition between liver, peripheral blood mononuclear cells and plasma. J Gen Virol 78: 1521-5. 
Moldvay J, Deny P, Pol S, Brechot C, Lamas E. 1994. Detection of hepatitis C virus RNA in peripheral blood mononuclear cells of infected patients by in situ hybridization. Blood. 83: 269-73.

Nakajima N, Hijikata M, Yoshikura H, Shimizu YK. 1996. Characterization of long-term cultures of hepatitis C virus. J Virol. 70: 3325-9.

Navas S, Martin J, Quiroga JA, Castillo I, Carreno V. 1998. Genetic diversity and tissue compartmentalization of the hepatitis $\mathrm{C}$ virus genome in blood mononuclear cells, liver, and serum from chronic hepatitis C patients. J Virol 72: 1640-6.

Odreman-Macchioli F, Baralle FE, Buratti E. 2001. Mutational analysis of the different bulge regions of hepatitis $\mathrm{C}$ virus domain II and their influence on internal ribosome entry site translational ability. J Biol Chem 276: 41648-55. Epub 2001 Aug 9.

Odreman-Macchioli FE, Tisminetzky SG, Zotti M, Baralle FE, Buratti E. 2000. Influence of correct secondary and tertiary RNA folding on the binding of cellular factors to the HCV IRES. Nucleic Acids Res 28: 875-85.

Okamoto H, Kanai N, Mishiro S. 1992. Full-length nucleotide sequence of a Japanese hepatitis $\mathrm{C}$ virus isolate (HC-J1) with high homology to USA isolates. Nucleic Acids Res 20: 6410 .

Okamoto H, Tokita H, Sakamoto M, Horikita M, Kojima M, Iizuka H, Mishiro S. 1993. Characterization of the genomic sequence of type V (or 3a) hepatitis $\mathrm{C}$ virus isolates and PCR primers for specific detection. J Gen Virol 74: 2385-90.

Oldstone MB. 1997. Viruses and autoimmune diseases. Scand J Immunol. 46: 320-5.

Pawlotsky JM. 2003a. Hepatitis C virus genetic variability: pathogenic and clinical implications. Clin Liver Dis 7: 45-66.

Pawlotsky JM. 2003b. Mechanisms of antiviral treatment efficacy and failure in chronic hepatitis C. Antiviral Res 59: 1-11. Write to the Help Desk NCBI | NLM | NIH 
Department of Health \& Human Services Privacy Statement | Freedom of Information Act | Disclaimer.

Pawlotsky JM. 2003c. Use and interpretation of hepatitis C virus diagnostic assays. Clin Liver Dis 7: 127-37. 4: Blight $\mathrm{KJ}$ et al. Efficient replication of hepa...[PMID: 12584342]Related Articles, Links.

Pawlotsky JM, Hovanessian A, Roudot-Thoraval F, Lebon P, Robert N, Bouvier M, Babany G, Duval J, Dhumeaux D. 1995. Activity of the interferon-induced 2',5'oligoadenylate synthetase in patients with chronic hepatitis C. J Interferon Cytokine Res 15: 857-62.

Pawlotsky JM, Hovanessian AG, Roudot-Thoraval F, Robert N, Bouvier M, Babany G, Duval J, Dhumeaux D. 1996. Effect of alpha interferon (IFN-alpha) on 2'-5' oligoadenylate synthetase activity in peripheral blood mononuclear cells of patients with chronic hepatitis C: relationship to the antiviral effect of IFN-alpha. Antimicrob Agents Chemother 40: 320-4.

Reynolds JE, Kaminski A, Carroll AR, Clarke BE, Rowlands DJ, Jackson RJ. 1996. Internal initiation of translation of hepatitis $\mathrm{C}$ virus RNA: the ribosome entry site is at the authentic initiation codon. Rna 2: 867-78.

Rijnbrand R, Bredenbeek P, van der Straaten T, Whetter L, Inchauspe G, Lemon S, Spaan W. 1995. Almost the entire 5' non-translated region of hepatitis $\mathrm{C}$ virus is required for cap-independent translation. FEBS Lett 365: 115-9.

Roque Afonso AM, Jiang J, Penin F, Tareau C, Samuel D, Petit MA, Bismuth H, Dussaix E, Feray C. 1999. Nonrandom distribution of hepatitis C virus quasispecies in plasma and peripheral blood mononuclear cell subsets. J Virol 73: 9213-21. 
Roque-Afonso AM, Ducoulombier D, Di Liberto G, Kara R, Gigou M, Dussaix E, Samuel D, Feray C. 2005. Compartmentalization of hepatitis C virus genotypes between plasma and peripheral blood mononuclear cells. J Virol. 79: 6349-57.

Rumin S, Berthillon P, Tanaka E, Kiyosawa K, Trabaud MA, Bizollon T, Gouillat C, Gripon P, Guguen-Guillouzo C, Inchauspe G, Trepo C. 1999. Dynamic analysis of hepatitis $\mathrm{C}$ virus replication and quasispecies selection in long-term cultures of adult human hepatocytes infected in vitro. J Gen Virol 80: 3007-18.

Samuel CE. 1998. Protein-nucleic acid interactions and cellular responses to interferon. Methods 15: 161-5.

Samuel CE. 2001. Antiviral actions of interferons. Clin Microbiol Rev 14: 778-809, table of contents.

Shimazaki T, Honda M, Kaneko S, Kobayashi K. 2002. Inhibition of internal ribosomal entry site-directed translation of $\mathrm{HCV}$ by recombinant IFN-alpha correlates with a reduced La protein. Hepatology 35: 199-208.

Shimizu YK, Igarashi H, Kanematu T, Fujiwara K, Wong DC, Purcell RH, Yoshikura H. 1997. Sequence analysis of the hepatitis C virus genome recovered from serum, liver, and peripheral blood mononuclear cells of infected chimpanzees. J Virol. 71: 5769-73.

Shimizu YK, Purcell RH, Yoshikura H. 1993. Correlation between the infectivity of hepatitis C virus in vivo and its infectivity in vitro. Proc Natl Acad Sci U S A. 90: 6037-41.

Soler M, Pellerin M, Malnou CE, Dhumeaux D, Kean KM, Pawlotsky JM. 2002. Quasispecies heterogeneity and constraints on the evolution of the 5' noncoding region of hepatitis $\mathrm{C}$ virus $(\mathrm{HCV})$ : relationship with $\mathrm{HCV}$ resistance to interferon-alpha therapy. Virology 298: 160-73. 
Tan SL, Katze MG. 2001. How hepatitis C virus counteracts the interferon response: the jury is still out on NS5A. Virology 284: 1-12. 17: Francois C et al. Expression of hepatitis C vir...[PMID: 10823866]Related Articles, Links.

Taylor DR, Puig M, Darnell ME, Mihalik K, Feinstone SM. 2005. New antiviral pathway that mediates hepatitis $\mathrm{C}$ virus replicon interferon sensitivity through ADAR1. J Virol 79: 6291-8.

Vizmanos JL, Gonzalez-Navarro CJ, Novo FJ, Civeira MP, Prieto J, Gullon A, GarciaDelgado M. 1998. Degree and distribution of variability in the 5' untranslated, E1, E2/NS1 and NS5 regions of the hepatitis C virus (HCV). J Viral Hepat 5: 227-40.

von Wagner M, Lee JH, Ruster B, Kronenberger B, Sarrazin C, Roth WK, Zeuzem S. 2003. Dynamics of hepatitis C virus quasispecies turnover during interferon-alpha treatment. J Viral Hepat 10: 413-22.

Vuillermoz I, Khattab E, Sablon E, Ottevaere I, Durantel D, Vieux C, Trepo C, Zoulim F. 2004. Genetic variability of hepatitis C virus in chronically infected patients with viral breakthrough during interferon-ribavirin therapy. J Med Virol 74: 41-53.

Yamamoto C, Enomoto N, Kurosaki M, Yu SH, Tazawa J, Izumi N, Marumo F, Sato C. 1997. Nucleotide sequence variations in the internal ribosome entry site of hepatitis C virus-1b: no association with efficacy of interferon therapy or serum HCV-RNA levels. Hepatology 26: 1616-20. 